\title{
INTERNATIONAL
}

JOURNAL OF
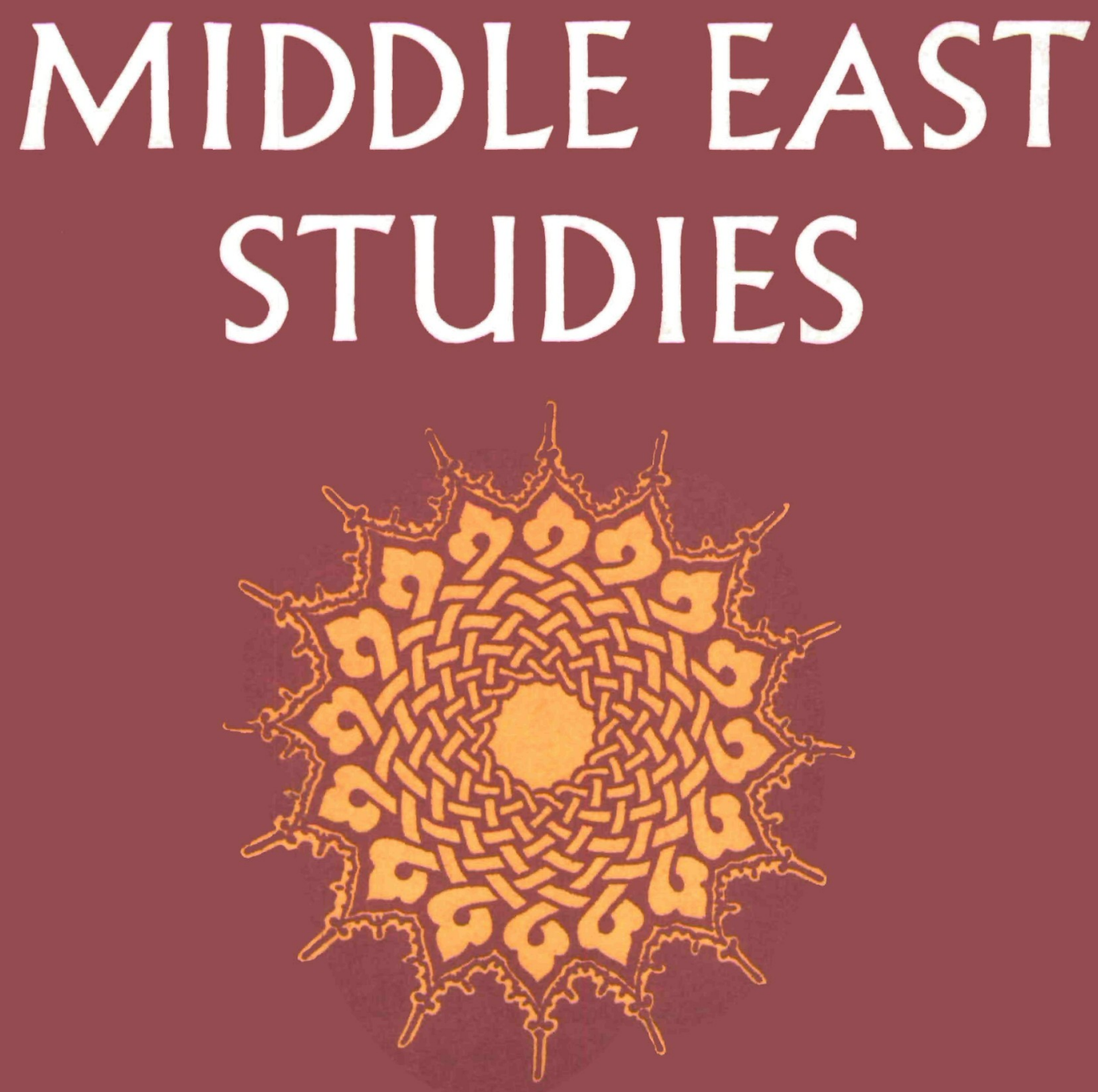

THE MIDDLE EAST STUDIES ASSOCIATION OF NORTH AMERICA 


\title{
INTERNATIONAL JOURNAL OF MIDDLE EAST STUDIES
}

Published under the auspices of The Middle East Studies Association of North America

\author{
Editor: Pfter voN Sivfrs \\ Associate Professor of Middle Eastern History. Liniversity of Ciah
}

\section{Book Review Editors}

Language and l.iterature Mo\A N. Miknall

Department of Near Eastern languages, New York Iniversits. New Yorh. Ne'w York I000)3

Social Sciences Micharl W. Silhimas

Departme'nt of Political Science. Kansas State Universit1. Manhattan. Kansas 6650h

History and Islamic Studies NAMCY E. GAI I H R

Department of History. Iniversity of California. Santa Barhara. (aliforma 9,3110n

Editorial Board

Janet L. ABt-L.tghod, Northwestern (niversul

Al BaNi azizi. Boston College

EDmind Burke, III, Cniversits of California, Santa ('ruz

Al t E. Hil l.al Dessot'ki. Cairo L'niversir!

Dalf F. Fickelman. New York Iniversity

Michati C. HIDSON, Georgeton'n Limiersil

Robert Mabro, St. Antony's College. Oxford

Fedwa Mal.ti-Dotglas, University of Texas at Austin

ERGLN OzztDin, Ankara liniversity

ANdré Raymond. Universite de Provence, Air-Marseille'

Frfdu Stambol li. Université de Tumis

Robret l.. TIgnor. Princelon Iniversill

El ias H. Tima, University of California. Davis

Josf:PH VAS Ess, Liniversität Tühinge'n

MESA and Cambridge University Press gratefully acknowledge the support provided to the Fditorial Office of IJMES by the Middle East Center, University of Utah.

The International Journal of Middle Fast Studies publishes articles and reviews concerning the area encompassing Iran. Turkey. Afghanistan. Israel. Pakistan and the countries of the Arab World from the seventh century to modern times. Spain, Southeastern Europe, and the Soviet Union also are included for the periods in which their territories were parts of the Middle Eastern empires or were under the influence of Middle Eastern civilization. Particular attention will be paid to works dealing with history. political science. economics. anthropology. sociology. philology and literature, folklore, comparative religion and theology. law and philosophy.

\section{c Cambridge University Press 1985}

\section{Copring}

This journal is registered with the Copyright Clearance Center (21 Congress St.. Salem MA 01970). Organizations in the U.S.A. who are also registered with C.C.C. may therefore copy material (beyond the limits permitted by sections 107 and 108 of the U.S. Copyright Law) subject to payment to C.C.C. of the per-copy fee indicated in the code on the first page of the article. This consent does not extend to multiple copying for promotional or commercial purposes.

IS/ Tear Service, 3501 Market Street, Philadelphia, Pennsylvania 19104. U.S.A., is authorized to supply single copies of separate articles for private use only.

For all other use. permission should be sought from the Cambridge or New York offices of the Cambridge University Press.

International Journal of Middle East Studies (ISSN 0020-7438) is published quarterly in February. May. August, and November. Four parts form a volume. The subscription price (which includes postage) for Volume 17. 1985 is $\$ 42.00$ net (US $\$ 80.00$ in the U.S.A. and Canada). Single parts cost $\$ 11.00$ net (US $\$ 24.00$ in the U.S.A. and (anada) plus postage. All subscribers to IJMES also receive the MESA Bulle'lin at no extra charge. Institutional orders may be sent to a bookseller, subscription agent, or to Cambridge University Press. The Edinburgh Building, Shaftesbury Road, Cambridge CB2 2RU, England, or in the U.S.A. and Canada to Cambridge University Press, 32 East 57th Street, New York, N.Y. 10022. Second class postage paid at New York, N.Y. and at additional mailing offices. Postmaster: send address changes to Int. J. Middle East Studies, Cambridge University Press, 32 East 57th Street, New York, N.Y. 10022.

Claims for missing issues should be made immediately after receipt of the next issue. 